\title{
A Case of Undifferentiated Carcinoma Originating from the Inferior Turbinate of Nasal Cavity
}

\author{
Dong Young Kim¹, Min Bum Kim¹, Chang Lim Hyun ${ }^{2}$, and Jeong Hong Kim ${ }^{1}$ \\ ${ }^{1}$ Departments of Otorhinolaryngology-Head and Neck Surgery, ${ }^{2}$ Pathology, Jeju National University School of Medicine, Jeju, Korea
}

비강 하비갑개에서 기원한 미분화암종 1 예

김동영 ${ }^{*} \cdot$ 김민범 $^{1} \cdot$ 현창림 $^{2} \cdot$ 김정홍 ${ }^{1}$

제주대학교 의학전문대학원 이비인후과학교실, ${ }^{1}$ 병리학교실 ${ }^{2}$

Received February 3, 2015

Revised February 19, 2015

Accepted April 30, 2015

Address for correspondence

Jeong Hong Kim, MD

Department of Otorhinolaryngology-

Head and Neck Surgery,

Jeju National University

School of Medicine,

102 Jejudaehak-ro,

Jeju 63243, Korea

Tel $+82-64-717-1716$

Fax $+82-64-717-1029$

E-mail sevent70@hanmail.net
Sinonasal undifferentiated carcinoma (SNUC) is a rare and highly aggressive malignant tumor arising from the schneiderian epithelium of the nasal cavity or paranasal sinuses. The presenting symptoms are diverse depending on the site involved and extent of tumor spread. The treatment of SNUC has evolved to improve overall survival rate and include disease-free control with complete surgical resection including radiotherapy and chemotherapy, but the prognosis still remains dismal. We present a patient with several months of history of intermittent nasal bleeding and stuffiness, which proved to be a rare malignant tumor of inferior turbinate origin, diagnosed as undifferentiated carcinoma of early stage in the disease process. The mass was excised en bloc with endoscopic surgical treatment from inferior turbinate without any additional combined treatment and there was no recurrence during the two-year follow-up period. We report herein, with a review of the literature, an undifferentiated carcinoma arising from the inferior turbinate, which was successfully treated by surgical resection only.

Korean J Otorhinolaryngol-Head Neck Surg 2015;58(10):704-9

Key Words Endoscopic surgery · Inferior turbinate - Sinonasal undifferentiated carcinoma.

\section{서 론}

비강 및 부비동내 발생한 미분화암종(sinonasal undifferentiated carcinoma)은 드물게 발생하지만 매우 침습적인 악 성종양으로 1986년 Frierson 등ํㅣㅇㅣ 처음 기술하였고, 현재까 지 약 200예 정도가 보고되어 있으나 최근 다른 악성종양과 의 감별 진단 기술의 발달로 임상적으로 보고되는 빈도가 증 가하고 있는 추세이다. 이 종양은 비강 schneiderian 상피막 혹은 부비동의 외배엽에서 기원하는 것으로 추정하고 있으며 병리 조직학적 소견 및 면역조직화학염색 검사로서만 진단이 가능한 질환으로 비강, 사골동, 접형동, 전두동, 상악동 순으 로 발생 빈도를 보이는 것으로 보고되고 있다. ${ }^{2}$ 발병 위치에 따라 코막힘, 비출혈, 콧물과 같은 단순 비염 증상에서부터 안와 내측이나 사골동 부위에서 기원하여 급속히 주변 조직
으로 침범시 안구 불편감이나 시력 저하, 뇌신경압박 등 다양 한 임상 증상이 나타날 수 있다. ${ }^{3)}$ 이에 저자들은 간헐적인 출 혈성 비루와 만성 비폐색을 호소하던 환자에서 하비갑개 내 측 전방부로부터 기원한 혈관성 종물에 대해 조기에 진단 및 치료를 위해 내시경하 종물 절제술을 시행하였고, 동결절편 조직검사상 악성종양으로 확인되어 종양이 부착된 하비갑개 골의 골막과 갑개골 부위를 포함하여 안전 변연을 확보하면 서 광범위 국소 절제술을 시행한 후 면역조직화검사를 통해 미분화암종으로 최종 확진된 1 예를 재발 및 전이 소견 없이 성공적으로 치료하였기에 문헌 고찰과 함께 보고하고자 한다.

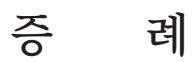

65세 남자 환자가 수개월 전부터 간헐적인 좌측 비강의 비 
출혈과 지속적인 코막힘을 호소하였고 내원 2주 전부터 좌 측 비강에서 혈괴가 뭉쳐 나오는 증상을 주소로 내원하였다. 코 외상의 과거력과 흡연력, 가족력은 없었다. 비내시경 검사 상 좌측 하비갑개 내측부에 약 $2.0 \times 1.5 \mathrm{~cm}$ 크기의 경계가 불명확한 혈관종성 종물이 관찰되었으며(Fig. 1), 거상기로 촉지시 비저부 외측부와 하비갑개 전방 하부에 단단히 부착

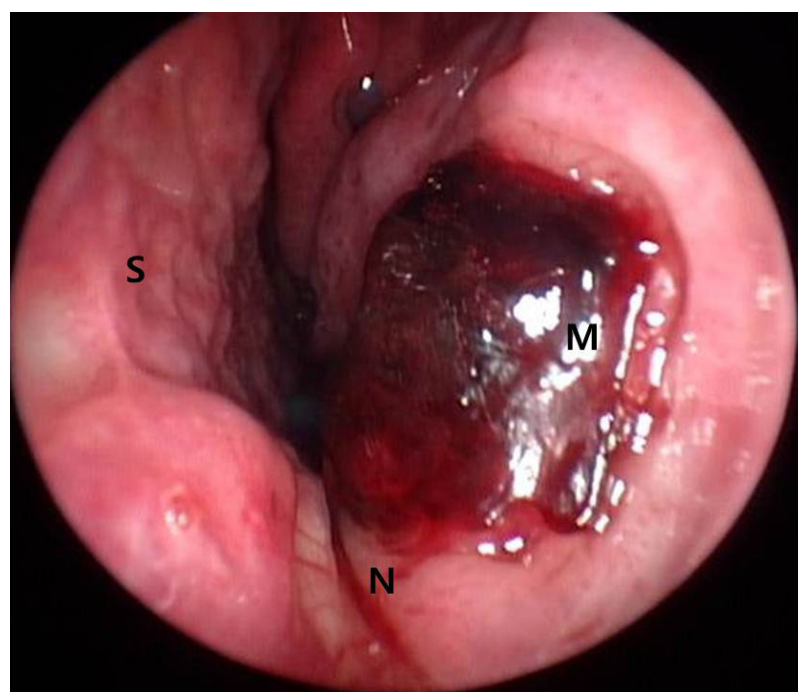

Fig. 1. Nasal endoscopic finding shows a smooth surfaced hemorrhagic mass arising from the left inferior turbinate. M: mass, $\mathrm{S}$ : septum, N: nasal floor.
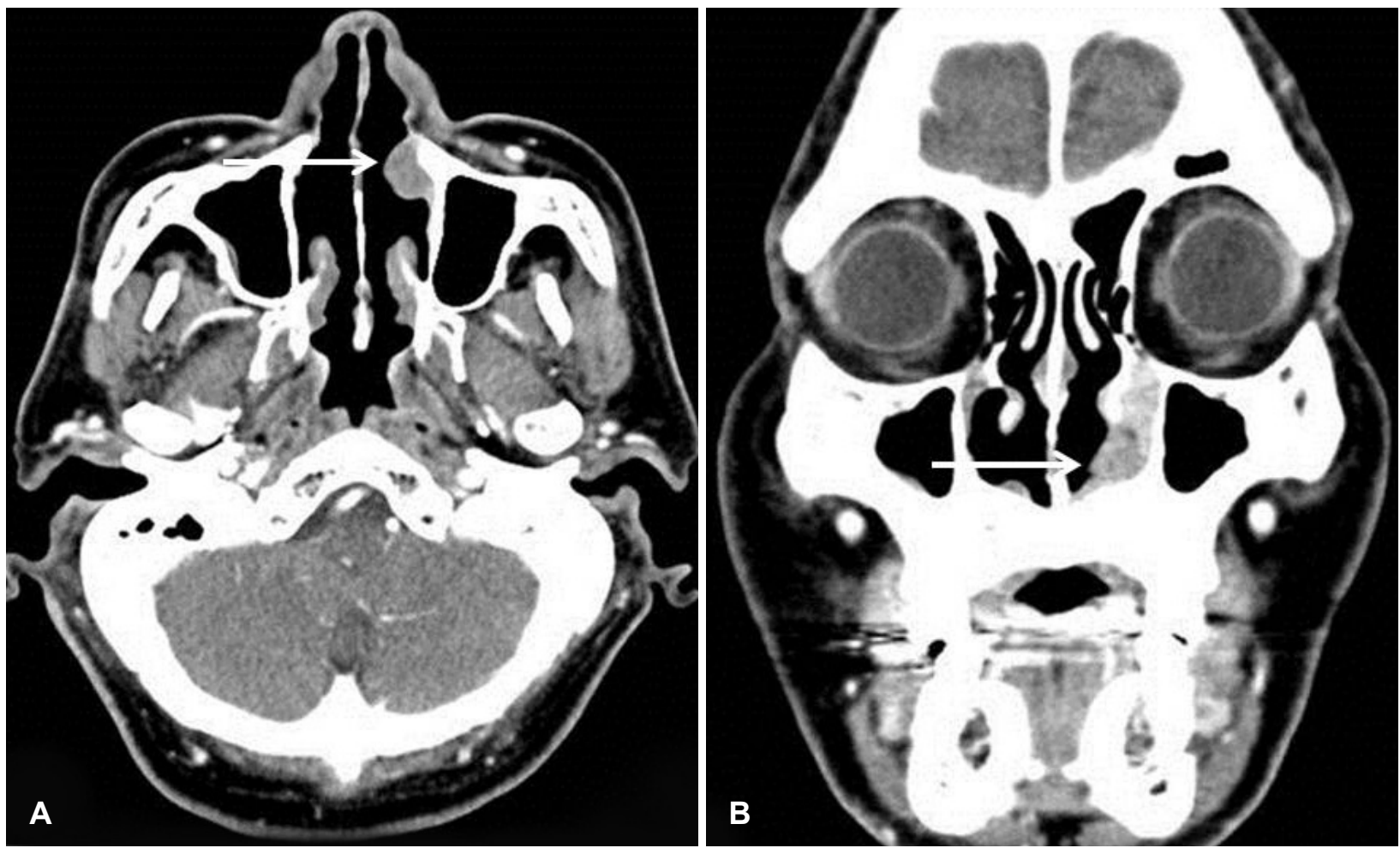

Fig. 2. Preoperative computed tomography scans demonstrate an oval shaped soft tissue mass (white arrow) with heterogenous enhancement attatched at the left inferior turbinate without any adjacent bony erosion. Axial view (A) and coronal view (B). 
$1.0 \mathrm{~cm}$ 크기의 난원형으로 고형 성분을 함유하고 있었다.

절제된 종물의 일부에 대해 동결절편 조직검사를 보낸 결 과 악성도가 높은 종양세포로 보고되었으며, 동결절편 검사 에서는 정확한 진단을 내리기가 어려워 추가 염색을 시행하
기로 하였으며, 절제 부위 경계면 점막에 대해서도 조직병리 검사를 보냈다. 한편, 악성종양 세포에 의한 하비갑개 골막 및 골 침범의 가능성을 고려하여 미세흡입절삭기(microdebrider)와 드릴을 이용하여 종물의 부착 기저부 및 변연부를
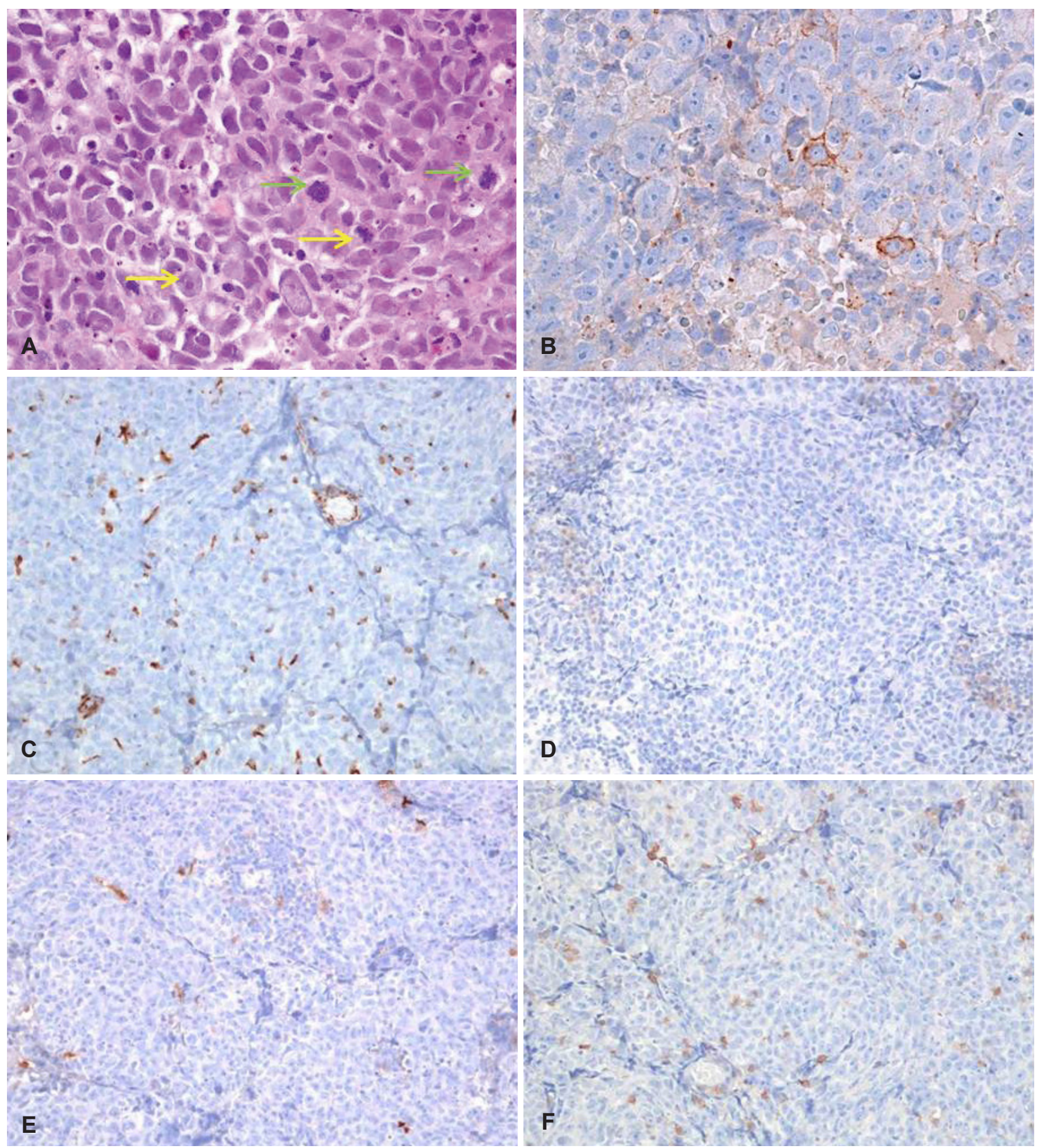

Fig. 3. Microscopic findings revealed pleomorphic and necrotic cells in the form of nest, lobules, and trabeculae without any squamous or glandular differentiation. The neoplastic cells have a high nuclear to cytoplasmic ratio and mitotic figures are increased (yellow arrow). And prominent tumor necrosis and apoptosis were found (green arrow) (H\&E stain, $\times 400)(A)$. Immunohistochemical assay demonstrated the positive reactivity of the neoplastic cells to cytokeratin (especially simple keratins, CK7, CK8 and CK19) (×400) (B). However, the tumor cells were negative for vimentin (C), neuron specific enolase (D), S-100 (E), and leukocyte common antigen (F) markers $(\times 100)$. Thus, the final diagnosis was proved to be undifferentiated carcinoma. 
추가 절제하였다. 최종 조직병리 검사 결과 종물의 안전 변연 은 확보되어 있었으며 원시적인 형태의 다각형 내지 둥근 세 포로 구성된 종양세포들이 둥지 혹은 육주형, 리본형으로 자 라고 있었으며 편평상피성 혹은 선형상의 분화는 보이지 않 았다. 핵은 과염색상을 보이면서 다수의 세포 분열이 관찰되 고, 핵 대 세포질의 비율은 매우 높고 중등도의 호산성 세포 질을 갖고 있었으며 주변 실질에 림프구의 침윤이 두드러져 있었다. 또한, 종양 둥지(tumor nest)에서는 종양세포의 세포 내 괴사 및 세포사멸(apoptosis)이 국소적으로 증가한 소견이 관찰되었다. 정확한 진단을 위해 시행한 면역조직화학염색 검 사에서 종양세포들은 상피세포 기원 표지자인 cytokeratin 7, 8, 19와 epithelial membrane antigen(EMA)에만 약하게 양 성 소견을 보였으며, 그 외 CD3, CD20, CD59, CD90, vimentin, neuron specific enolase(NSE), S-100 단백질, leukocyte common antigen(LCA), human melanoma black 45(HMB45), chromogranin A, synaptophysin, desmin, myoDl에 대해서 는 모두 음성 소견을 보여 미분화 상태의 암종으로 최종 판 명되었다(Fig. 3). 수술 후 경부 림파선 및 기타 장기로 전이 여부를 확인하기 위하여 시행한 전신 양전자방출컴퓨터단층 촬영(positron emission tomography-CT) 검사상에서는 별 다른 이상 소견이 관찰되지 않았다. 조직학적 검사상 하비갑 개 절제 변연의 안전함이 확인되어 부비동 미분화암종 발생 초기에 진단된 것으로 판단하였으며, 추가 항암치료 및 방사 선치료는 시행하지 않았고, 환자에게는 국소 재발 혹은 전이 소견이 의심될 경우 추가 치료를 계획해야 함을 주지시켰으 며, 현재 24개월간 외래 추적 관찰시 하비갑개 점막의 국소 비후나 괴사, 출혈 등 병적 소견 및 재발의 증거는 관찰되지 않는 상태이다(Fig. 4).

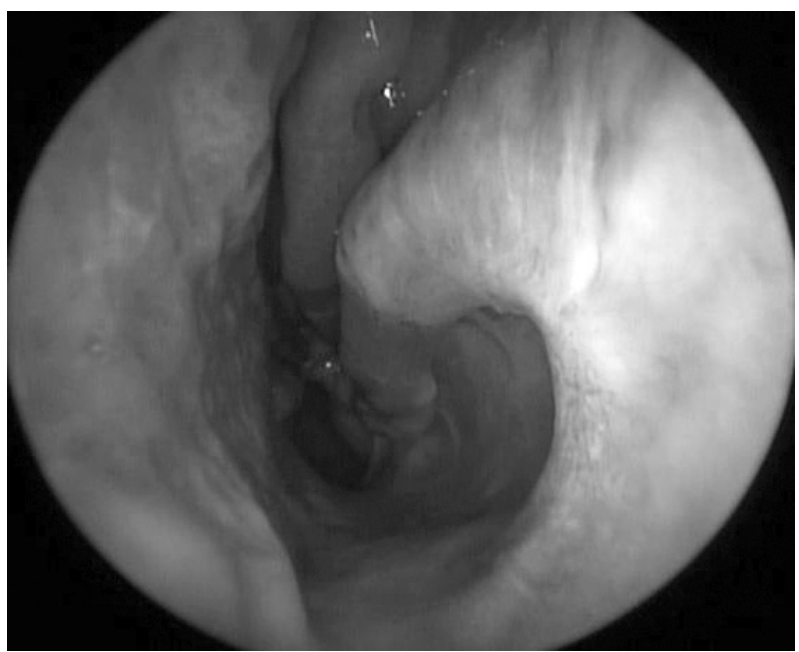

Fig. 4. Postoperative endoscopic view of the left nasal cavity after 2-year follow-up. Any recurrence findings of undifferentiated carcinoma from the inferior turbinate were not noted.

\section{고 찰}

비강내에서 단일 종괴 형태를 띠면서 일측성으로 비폐색 과 비충만감, 간헐적인 비출혈을 호소하는 경우 비침습적인 양상의 종괴라면 우선적으로 혈관종이나 혈관섬유종, 신경 초종, 림프관종, 유피낭종, 거대세포종, 유두종, 다형 선종 등 을 의심할 수 있으나, 영상학적 검사상 주변 골조직이나 연부 조직, 안구, 뇌기저부 등으로 침범하는 양상의 종괴라면 악성 흑색종, 악성 림프종, 연골육종, 횡문근육종, 림프상피종, 선 양낭성 암종, 신경내분비암종, 후각신경아세포종, 악성섬유성 조직구증, 혈관주위세포종, 그리고 드물게는 미분화암종 등 을 의심해 봐야 한다.,5) 비강내 발생하는 악성종양은 전체 악성종양의 약 $1 \%$ 미만을, 그리고 전체 두경부 종양에서는 대략 3 4\%를 차지하며 그 중 하비갑개에서 기원한 악성종양 은 지금까지 비호치킨 림프종, 유잉육종(Ewing's sarcoma), 편평상피세포암, 흑색종, 림프아세포성육종, 선편평암종, 골 육종 등이 보고되었지만(6) 미분화암종이 단일 종괴로 하비갑 개에서 기원한 예는 극히 드문 것으로 보고되고 있다. 비부비 동 미분화암종은 두경부에서 발생하는 암종 중에서도 드물게 발병하는 악성 종양으로 비강, 사골동, 상악동 등에서 주로 발 생하는 것으로 보고되었으며 침습적으로 진행시에는 안와 지판, 익돌구개와, 시상판, 뇌경막 등 주변 중요 구조를 공격 적으로 침범하는 것으로 알려져 있다. 발병 초기에는 간헐적 인 비출혈, 코막힘, 출혈성 비루 등의 일반적인 비질환 증상을 보이다가 부비동 주변 안구나 뇌기저부로 급격히 진행되는 경 우에 안구 돌출, 안구 통증, 안면통, 시력 저하 및 뇌신경 압박 증상을 호소하게 된다. 발병 연령은 넓게 분포되어 있으나 중 간 연령은 50대이며 남성에서 2 3:1의 편향을 보인다. 발생 원 인은 아직까지도 정확히 밝혀진 바가 없으나 Epstein-Barr 바이러스가 원인일 수 있다는 보고가 일부 있었지만 현재의 연구 결과 직접적인 관련은 없는 것으로 받아들여지고 있 다.) 또한 과도한 흡연이 원인이 될 수 있으며 비인강암으로 방사선치료를 받은 환자에게서 발생하였다는 보고도 있었 다. ${ }^{8)}$ Phillips 등')은 컴퓨터전산화단층촬영에서는 다양한 정 도로 조영 증강을 보이면서 대부분 석회화 소견이 없고 종괴 의 경계가 불명확하고 주로 비강 상부에서 병이 기원하며 주 변 골파괴를 동반하면서 이웃해 있는 부비동을 포함하여 전 두개와, 안구, 익돌구개와, 부인두강, 해면정맥동까지 침범하는 것으로 보고하였다. 자기공명영상 검사에서 $\mathrm{T} 1$ 강조영상에서 는 근육의 신호강도와 비슷하게, $\mathrm{T} 2$ 강조영상에서는 근육과 비슷하거나 강한 신호강도를 보이고, gadolinium 조영 증강 영상에서는 불균일한 신호강도를 보이는 것으로 보고하였다. 영상학적 검사만으로는 비강내 발생한 미분화성 암종과 양 
성 종양 및 악성종양을 명확히 구분할 수 있는 특징적인 소 견은 없다고 하였으며, 다만 조직 병리학적 소견과 면역조직 화학염색을 통해 이미 알려져 있는 종양 특이 표지자의 반응 결과를 보고 판단을 해야 한다고 하였다. 본 증례에서는 상 피세포 기원의 표지자인 cytokeratin, EMA에만 양성 반응 을 보였으며, 림프종과의 감별을 위한 CD3, CD20, CD56, CD90, LCA, 그리고 간엽세포 기원 종양표지자인 vimentin 과 멜라닌 세포 혹은 신경초 기원 표지자인 S-100, HMB45 에는 음성 반응을 보였고, 신경아세포종이나 폐소세포암에 특이적인 NSE, chromogranin A, 신경내분비암종의 표지자 인 synaptophysin, 그리고 횡문근육종의 표지자인 desmin, myoD1에 대해 모두 음성 반응을 보였으며, Ebstein-Barr 바이 러스에 대한 Epstein-Barr virus encoded small RNA-1의 제자 리부합화(in-situ hybridization) 검사에서도 모두 음성으로 결과가 나와 Park 등ํ)이 보고한 하비갑개 기원 미분화암종 진단에 있어서 cytokeratin, CD56, 그리고 neuron specific enolase 염색 결과에 근거하여 진단한 것과 비교하여 종양 특이적 감별 염색진단을 다각적으로 시행하여 미분화암종으 로 최종 판명되었다.

비부비동 미분화암종의 드문 발생 빈도와 대조군 연구의 미흡으로 인해 아직까지도 최적의 치료 방법에 대한 의견 합 의가 이루어지지 않은 상태이다. 생존율 향상과 암 병변의 성 장 억제를 위한 광범위 외과적 절제술과 항암, 방사선치료를 널리 사용해 왔지만 2년 평균 생존율이 처음 진단이 내려진 후 25 67\%로 만족할 만한 결과를 얻지 못하고 있다. ${ }^{11)}$ 뇌기 저부나 안와, 해면정맥동 등을 침범한 미분화암종의 경우 과 거 고식적인 광범위 두개안면절제술을 통한 수술적 치료로 는 술 후 심각한 뇌척수액 유출 및 안면 흥터, 두개내 합병증 등을 유발하였으나, 최근 Revenaugh 등르는 부비동 내시경과 영상유도 항법장치(image-guided navigation system)를 병 용한 최소 침습적 두개안면절제술과 동시 화학방사선요법을 시행하면서 종양을 완전 절제하고 신경기능과 시력을 보존하 게 되면서 합병증이 감소되어 2 년 평균 생존율이 $85 \%$, 무병 생존율이 $71 \%$ 로 증가하였다고 보고하였다. 그러나 전두동 전벽, 안와 상부 외측, 해면정맥동, 뇌경막 혹은 두개내로 침 범한 진행성 미분화암종의 경우에는 수술적 치료의 효용이 적고 화학방사선치료의 한계에 부딧혀 예후가 극히 나쁜 것 으로 보고하였다. 하지만 Jeng 등흐는 비강과 사골동에서 기 원한 미분화암이더라도 주변 조직으로 침범하거나 전이 소견 이 없이 국소적으로 제한된 경우에는 수술적 치료만으로도 31 개월의 추적관찰 기간 동안 병의 재발 소견이 없었다고 보 고하였다. Park 등신은 하비갑개 후하연에서 기원하여 미분 화암종으로 조기에 진단된 종괴에 대해서 내시경을 이용한
최소침습수술로 원발 부위 종양의 완전 관해를 이루었다고 보고한 것처럼 본 증례도 비강내 하비갑개에 국소적으로 발 생하고 주변 골조직으로의 침습이 진행되기 전 매우 초기 단 계에 악성 진단이 내려지는 경우에 한해서는 내시경적으로 원 발 부위에서 자유 변연을 충분히 확보하고 골 침습의 가능성 을 고려하여 골막을 포함하여 병변의 부착 부위를 광범위하 게 절제해주면 화학방사선치료와 같은 추가적인 치료를 시행 하지 않더라도 수술적인 치료만으로도 무병 생존율에 있어서 만족할 만한 결과를 얻을 수 있다고 판단된다. 또한 최근에는 비부비동 미분화암종의 예후를 예측하는 데 있어 urokinase plasminogen receptor 혹은 c-kit tyrosine kinase receptor와 같 은 종양 표지자가 세포내 발현이 증가하는 경우 침습과 전이 를 공격적으로 한다는 연구 결과를 바탕으로 수술적 절제 후 이들 물질의 활성을 억제하는 물질을 투여하는 생물학적 맞 춤형 치료가 연구 중이다. ${ }^{14,15)}$ 결론적으로 비부비동에서 발생 한 미분화암종은 매우 침습적이고 급속히 진행하는 암종이므 로 원발 부위에서 재발 및 경부 혹은 기타 장기로 원격 전이 가 일어날 가능성을 항상 염두에 두고 장기간의 추적 관찰이 꼭 필요하다고 보며 병의 진행 상태 및 환자의 조건에 맞는 최 적의 치료 방법을 선택하는 것이 가장 중요하다고 생각된다.

\section{Acknowledgments}

This research was supported by the 2015 scientific promotion program funded by Jeju National University.

\section{REFERENCES}

1) Frierson HF Jr, Mills SE, Fechner RE, Taxy JB, Levine PA. Sinonasal undifferentiated carcinoma. An aggressive neoplasm derived from schneiderian epithelium and distinct from olfactory neuroblastoma. Am J Surg Pathol 1986;10(11):771-9.

2) Goel R, Ramalingam K, Ramani $P$, Chandrasekar T. Sino nasal undifferentiated carcinoma: a rare entity. J Nat Sci Biol Med 2012;3(1): 101-4.

3) Bae CH, Jung DH, Byun JY, Lee JY. A case of sinonasal undifferentiated carcinoma originating from the ethmoid sinus. Korean J Otorhinolaryngol-Head Neck Surg 2009;52(6):536-40.

4) Thompson LDR. Sinonasal carcinomas. Curr Diagn Pathol 2006; 12(1):40-53.

5) Ikeda K, Tanno N, Suzuki H, Oshima T, Kano S, Takasaka T. Unilateral sinonasal disease without bone destruction. Differential diagnosis using diagnostic imaging and endonasal endoscopic biopsy. Arch Otolaryngol Head Neck Surg 1997;123(2):198-200.

6) Wenig BM. Undifferentiated malignant neoplasms of the sinonasal tract. Arch Pathol Lab Med 2009;133(5):699-712.

7) Cerilli LA, Holst VA, Brandwein MS, Stoler MH, Mills SE. Sinonasal undifferentiated carcinoma: immunohistochemical profile and lack of EBV association. Am J Surg Pathol 2001;25(2):156-63.

8) Franchi A, Moroni M, Massi D, Paglierani M, Santucci M. Sinonasal undifferentiated carcinoma, nasopharyngeal-type undifferentiated carcinoma, and keratinizing and nonkeratinizing squamous cell carcinoma express different cytokeratin patterns. Am J Surg Pathol 2002;26(12):1597-604.

9) Phillips CD, Futterer SF, Lipper MH, Levine PA. Sinonasal 
undifferentiated carcinoma: CT and MR imaging of an uncommon neoplasm of the nasal cavity. Radiology 1997;202(2):477-80.

10) Park TJ, Kim BY, Kim SW, Kwon JH. A case of endoscopic resection of sinonasal undifferentiated carcinoma originating from inferior turbinate. J Clinical Otolaryngol 2013;24(2):280-4.

11) Righi PD, Francis F, Aron BS, Weitzner S, Wilson KM, Gluckman J. Sinonasal undifferentiated carcinoma: a 10-year experience. Am J Otolaryngol 1996;17(3):167-71.

12) Revenaugh PC, Seth R, Pavlovich JB, Knott PD, Batra PS. Minimally invasive endoscopic resection of sinonasal undifferentiated carcinoma. Am J Otolaryngol 2011;32(6):464-9.

13) Jeng YM, Sung MT, Fang CL, Huang HY, Mao TL, Cheng W, et al.
Sinonasal undifferentiated carcinoma and nasopharyngeal-type undifferentiated carcinoma: two clinically, biologically, and histopathologically distinct entities. Am J Surg Pathol 2002;26(3): 371-6.

14) Xu CC, Dziegielewski PT, McGaw WT, Seikaly H. Sinonasal undifferentiated carcinoma(SNUC): the Alberta experience and literature review. J Otolaryngol Head Neck Surg 2013;42:2.

15) Chernock RD, Perry A, Pfeifer JD, Holden JA, Lewis JS Jr. Receptor tyrosine kinases in sinonasal undifferentiated carcinomas-evaluation for EGFR, c-KIT, and HER2/neu expression. Head Neck 2009;31(7):919-27. 